\title{
KOMPETENSI PENGADILAN TATA USAHA NEGARA
}

$\begin{array}{ll}\text { Nama } & \text { : AHMAD RIAN ALJAZIM } \\ \text { Email } & : \text { riyanaljazim@ gmail.com } \\ \text { No BP } & : 2010003600465 \\ \text { PTS } & : \text { Universitas Eka Sakti }\end{array}$

\section{A. PENDAhuluan}

Keberadaan Peradilan Tata Usaha Negara di Indonesia dimulai dengan lahirnya UndangUndang nomor 5 tahun 1986 tentang Peradilan Tata Usaha Negara sebagaimana telah diubah dengan Undang-Undang nomor 9 tahun 2004 dan Undang-Undang nomor 51 tahun 2009 serta mulai beroperasi pertama kali pada tanggal 14 Januari 1991 dengan diterbitkan PP No.7 Tahun 1991 tentang penerapan Undang-Undang nomor 5 tahun 1986 tentang Peradilan Tata Usaha Negara, Undang-Undang Republik Indonesia No. 10 Tahun 1990 tentang pembentukan PT.TUN Jakarta, Medan dan Ujung Pandang serta Keppres No. 52 Tahun 1990 tentang pembentukan PTUN Jakarta, Medan, Palembang, Surabaya dan Ujung Pandang, sekarang telah meliputi 4 Pengadilan Tinggi TUN serta 26 Pengadilan Tata Usaha Negara.

Dalam Pasal 47 Undang-Undang nomor 5 tahun 1986 tentang Peradilan Tata Usaha Negara sebagaimana telah diubah dengan UndangUndang nomor 9 tahun 2004 dan Undang-Undang nomor 51 tahun 2009 telah diatur tentang kompetensi PTUN dalam sistem peradilan di Indonesia yaitu bertugas dan berwenang memeriksa, memutus, dan menyelesaikan sengketa tata usaha negara.

Kewenangan Pengadilan untuk menerima, memeriksa, memutus menyelesaikan perkara yang diajukan kepadanya yang dikenal dengan kompetensi atau kewenangan mengadili. Pengadilan TUN mempunyai kompetensi menyelesaikan sengketa tata usaha negara di tingkat pertama, Pengadilan Tinggi Tata Usaha Negara untuk tingkat banding dan Mahkamah Agung untuk tingkat kasasi dan peninjauan kembali.

Khusus untuk sengketa-sengketa tata usaha negara yang harus diselesaikan terlebih dahulu melalui upaya administrasi sebagaimana diatur dalam pasal 48 Undang-Undang nomor 5 tahun 1986 tentang Peradilan TUN sebagaimana telah dirubah dengan UndangUndang nomor 9 Tahun 2004 dan Undang-Undang nomor 51 tahun 2009 maka 
Pengadilan Tinggi TUN dapat memeriksa, memutus dan menyelesaikannya sebagai badan peradilan tingkat pertama dan terhadap putusan PT.TUN tersebut tidak tersedia upaya hukum banding melainkan langsung mengajukan upaya hukum kasasi ke Mahkamah Agung.

Berdasarkan hal-hal tersebut maka dalam tulisan ini akan dibahas mengenai "Kompetensi Peradilan TUN dalam Sistem Peradilan di Indonesia”.

\section{B. PEMBAHASAN}

Kompetensi (kewenangan) suatu badan pengadilan untuk mengadili suatu perkara dapat dibedakan atas kompetensi relatif dan kompetensi absolut. Kompetensi relatif berhubungan dengan kewenangan pengadilan untuk mengadili suatu perkara sesuai dengan wilayah hukumnya. Sedangkan kompetensi absolut adalah kewenangan pengadilan untuk mengadili suatu perkara menurut obyek, materi atau pokok sengketa.

a. Kompetensi Relatif Kompetensi relatif suatu badan pengadilan ditentukan oleh batas daerah hukum yang menjadi kewenangannya. Suatu badan pengadilan dinyatakan berwenang untuk memeriksa suatu sengketa apabila salah satu pihak sedang bersengketa (Penggugat/Tergugat) berkediaman di salah satu daerah hukum yang menjadi wilayah hukum pengadilan itu.

Untuk Pengadilan Tata Usaha Negara, kompetensi relatifnya diatur dalam Pasal 6 UU No. 5 Tahun 1986 tentang Peradilan TUN sebagaimana telah diubah dengan UU No. 9 Tahun 2004 dan UU NO. 51 tahun 2009 menyatakan:

1. Pengadilan Tata Usaha Negara berkedudukan di ibukota Kabupaten/Kota, dan daerah hukumnya meliputi wilayah Kabupaten/Kota.

2. Pengadilan Tinggi Tata Usaha Negara berkedudukan di ibukota Provinsi dan daerah hukumnya meliputi wilayah Provinsi.

Pada saat ini Pengadilan Tata Usaha Negara di Indonesia baru terdapat di 26 Propinsi dan Pengadilan Tinggi Tata Usaha Negara baru terdapat 4 yaitu PT.TUN Medan, Jakarta, Surabaya dan Makassar sehingga wilayah hukum PTUN meliputi beberapa kabupaten dan kota. Sedangkan PT.TUN wilayah hukumnya meliputi beberapa provinsi, seperti PTUN Jakarta yang meliputi wilayah kota yang ada di Daerah khusus ibu kota Jakarta 
Raya sedangkan PT.TUN Jakarta meliputi beberapa Propinsi yang ada di pulau Kalimantan, Jawa Barat dan DKI.

Adapun kompetensi yang berkaitan dengan tempat kedudukan atau tempat kediaman para pihak yang bersengketa yaitu Penggugat dan Tergugat diatur tersendiri dalam pasal 54 UU No. 5 Tahun 1986 tentang Peradilan Tata Usaha Negara sebagaimana telah diubah dengan UU No. 9 tahun 2004 dan UU No. 51 tahun 2009 yang menyebutkan:

1. Tempat kedudukan Tergugat;

2. Tempat Kedudukan salah satu Tergugat;

3. Tempat kediaman Penggugat diteruskan ke Pengadilan tempat kedudukan Tergugat;

4. Tempat kediaman Penggugat, (dalam keadaan tertentu berdasarkan Peraturan Pemerintah);

5. PTUN Jakarta, apabila tempat kediaman Penggugat dan tempat kedudukan Tergugat berada diluar negeri;

6. Tempat kedudukan Tergugat, bila tempat kediaman Penggugat di luar negeri dan tempat kedudukan Tergugat didalam negeri.

Dengan ketentuan tersebut maka pada prinsipnya gugatan diajukan ke pengadilan TUN di tempat kedudukan Tergugat sedangkan yang bersifat eksepsional di Pengadilan TUN tempat kedudukan Penggugat diatur kemudian setelah ada Peraturan Pemerintah, akan tetapi sampai sekarang ini Peraturan Pemerintah yang dimaksud belum ada sehingga belum dapat diterapkan.

b. Kompetensi Absolut Kompetensi absolut suatu badan pengadilan adalah kewenangan yang berkaitan untuk mengadili suatu perkara menurut obyek atau materi atau pokok sengketa. Adapun yang menjadi obyek sengketa di Pengadilan Tata Usaha Negara adalah Keputusan Tata Usaha Negara (Beschikking) Yang diterbitkan oleh Badan/Pejabat TUN. Sebagaimana disebutkan dalam pasal 1 angka 9 UU No. 51 Tahun 2009 tentang Perubahan Kedua UU No. 5 Tahun 1986 tentang Peradilan Tata Usaha Negara. Sedangkan perbuatan Badan/Pejabat TUN lainnya baik perbuatan materiil (material daad) maupun penerbitan peraturan (regeling) masing-masing merupakan kewenangan Peradilan Umum dan Mahkamah Agung 
Kompetensi absolut Pengadilan TUN diatur dalam pasal 1 angka 10 UU No. 51 tahun 2009 tentang Perubahan Kedua UU No. 5 Tahun 1986 tentang Peradilan Tata Usaha Negara, yang menyebutkan:

"Sengketa tata usaha Negara adalah sengketa yang timbul dalam bidang Tata Usaha Negara antara orang atau Badan Hukum Perdata dengan Badan atau Pejabat tata usaha negara, baik di pusat maupun di daerah, sebagai akibat dikeluarkannya Keputusan tata usaha negara, termasuk sengketa kepegawaian berdasarkan peraturan perundangundangan yang berlaku"

Sedangkan yang dimaksud Keputusan Tata Usaha Negara menurut ketentuan Pasal 1 angka 9 UU No. 51 tahun 2009 tentang perubahan kedua UU No. 5 Tahun 1986 tentang Peradilan Tata Usaha Negara adalah suatu penetapan tertulis yang dikeluarkan oleh Badan/Pejabat TUN yang berisi tindakan hukum TUN berdasarkan peraturan perundangundangan yang berlaku, yang bersifat konkrit, individual dan final sehingga menimbulkan akibat hukum bagi seseorang atau badan hukum perdata.

Dari rumusan pasal tersebut, persyaratan keputusan TUN yang dapat menjadi obyek di Pengadilan TUN meliputi :

1. Penetapan tertulis;

2. Dikeluarkan oleh Badan/Pejabat TUN;

3. Berisi tindakan hukum TUN;

4. Berdasarkan peraturan perundang-undangan yang berlaku;

5. Bersifat konkrit, individual dan final;

6. Menimbulkan akibat hukum bagi seseorang atau badan hukum perdata.

Keenam persyaratan tersebut bersifat komulatif, artinya untuk dapat dijadikan obyek sengketa di Peradilan TUN, keputusan TUN harus memenuhi keenam persyaratan tersebut.

Selain itu kompetensi Peradilan TUN termasuk pula ketentuan yang terdapat dalam ketentuan pasal 3 UU Peratun, yaitu dalam hal Badan/Pejabat TUN tidak mengeluarkan suatu keputusan yang dimohonkan kepadanya sedangkan hal itu merupakan kewajibannya.

Dalam praktek keputusan-keputusan badan/Pejabat TUN yang berpontesi menimbulkan sengketa TUN, yaitu antara lain : 


\section{1) Keputusan tentang Perijinan}

Secara yuridis suatu ijin adalah adalah merupakan persetujuan yang diberikan pemerintah (Badan/Pejabat TUN) kepada seseorang atau badan hukum perdata untuk melakukan aktivitas tertentu. Menurut Prof. Dr. Pilipus M. Hadjon, SH2 tujuan diadakannya perijinan pada pokoknya adalah :

a. Mengarahkan atau mengendalikan aktivitas tertentu (misalkan: ijin prinsip, IMB, ijin pertambangan, ijin pengusahaan hutan, ijin berburu, dsb);

b. Mencegah bahaya atau gangguan (misalkan: gangguan/ herder ordonantie, amdal, dsb);

c. Melindungi obyek tertentu (misalkan: ijin masuk obyek wisata, cagar budaya, dsb); d. Distribusi benda atau barang lelang (misalkan: ijin trayek, ijin perdagangan satwa langka, dsb);

d. Seleksi orang atau aktivitas tertentu (misalkan: SIM, ijin memiliki senjata api, ijin penelitian, dsb).

2) Keputusan tentang Status Hukum, Hak dan Kewajiban

a. Status hukum perorangan atau Badan Hukum Perdata, misalkan: akta kelahiran, akta kematian, akta pendirian/pembubaran badan hukum, KTP, Ijazah, Sertifikat (Tanda Lulus Ujian), dsb);

b. Hak/ Kewajiban perorangan atau Badan Hukum Perdata terhadap suatu barang untuk jasa, misalkan: pemberian/pencabutan hak atas tanah, hak untuk melakukan pekerjaan, dsb).

3) Keputusan tentang Kepegawaian

a. Keputusan tentang mutasi PNS, dimana pegawai yag dimutasi keberatan karena merasa dirugikan, menghambat karier atau karena mutasi itu dianggap hukuman disiplin terselubung;

b. Keputusan tentang hukuman disiplin PNS, dimana pegawai yang bersangkutan menganggap hukuman itu tidak sesuai prosedur atau tidak adil;

c. Keputusan tentang pemberhentian PNS, misalnya dalam rangka perampingan pegawai atau likuidasi suatu instansi, dsb.

Akan tetapi kompetensi Pengadilan Tata Usaha Negara sebagaimana disebutkan dalam pasal 1 angka 9 UU No. 51 tahun 2009 tentang perubahan kedua UU No. 5 
Tahun 1986 tentang Peradilan Tata Usaha Negara, dibatasi oleh ketentuan pasal 2, Pasal 48, Pasal 49 dan Pasal 142 Undang-Undang Peradilan tersebut, sehingga Pembatasan terhadap objek sengketa Pengadilan Tata Usaha Negara tersebut dibedakan menjadi : Pembatasan langsung, pembatasan tidak langsung dan pembatasan langsung bersifat sementara:

1) Pembatasan Langsung

Pembatasan langsung adalah pembatasan yang tidak memungkinkan sama sekali bagi Pengadilan Tata Usaha Negara untuk memeriksa, memutus sengketa dan menyelesaikan sengketa tersebut. Hal tersebut disebutkan secara tegas dalam penjelasan Undang-Undang Peratun yaitu :

a. Pasal 2 Undang-Undang Peratun

1. Keputusan tata usaha negara yang merupakan perbuatan hukum perdata.

2. Keputusan tata usaha negara yang merupakan pengaturan yang bersifat umum.

3. Keputusan tata usaha negara yang masih memerlukan persetujuan.

4. Keputusan tata usaha negara yang dikeluarkan berdasarkan Kitab UndangUndang Hukum Pidana atau Kitab UndangUndang Hukum Acara Pidana atau peraturan perundangundangan lain yang bersifat hukum pidana.

5. Keputusan tata usaha negara yang dikeluarkan atas dasar hasil pemeriksaan badan peradilan berdasarkan ketentuan peraturan perundangundangan yang berlaku.

6. Keputusan tata usaha negara mengenai tata usaha Tentara Nasional Indonesia.

7. Keputusan Komisi Pemilihan Umum baik di pusat maupun di daerah, mengenai hasil pemilihan umum.

b. Pasal 49 Undang-Undang Peratun Pengadilan tidak berwenang memeriksa, memutus dan menyelesaikan sengketa tata usaha negara tertentu dalam hal keputusan tata usaha negara yang disengketakan itu dikeluarkan:

1) Dalam waktu perang, keadaan bahaya, keadaan bencana alam atau keadaan luar biasa yang membahayakan berdasarkan peraturan perundangundangan yang berlaku. 
2) Dalam keadaan mendesak untuk kepentingan umum berdasarkan peraturan perundang-undangan yang berlaku.

2) Pembatasan Tidak Langsung

Pembatasan tidak langsung adalah pembatasan yang masih membuka kemungkinan bagi PT.TUN untuk memeriksa, memutus dan menyelesaikan sengketa administrasi dengan ketentuan seluruh upaya administratif yang tersedia telah ditujukan terlebih dahulu oleh Orang/ Badan Hukum Perdata.

Pembatasan tidak langsung tersebut terdapat dalam ketentuan Pasal 48 UU No. 5 Tahun 1986 tentang Peratun sebagaimana telah diubah dengan Undang-Undang No. 9 Tahun 2004 dan UU No. 51 tahun 2009 yang berbunyi :

(1) Dalam hal suatu Badan atau Pejabat tata usaha negara diberi wewenang oleh atau berdasarkan peraturan perundangundangan untuk menyelesaikan secara administratif sengketa tata usaha negara tersebut harus diselesaikan melalui upaya administratif yang tersedia.

(2) Pengadilan baru berwenang memeriksa, memutus, dan menyelesaikan sengketa tata usaha negara sebagaimana dimaksud dalam ayat (1) jika seluruh upaya adminisratif yang bersangkutan telah digunakan.

Berdasarkan pembatasan tidak langsung tersebut, jika upaya administratif (administratief beroep) yang tersedia telah ditempuh dan pihak Penggugat masih dirugikan, maka secara tegas dalam ketentuan pasal 51 ayat 3 Undang-Undang Peardilan Tata Usaha Negara yang berbunyi sebagai berikut :

"Pengadilan Tinggi Tata Usaha Ngara bertugas dan berwenang memeriksa, memutus, dan menyelesaikan di tingkat pertama sengketa Tata Usaha Negara sebagaimana dimaksud dalam Pasal 48."

3) Pembatasan langsung yang bersifat sementara

Pembatasan ini bersifat langsung karena tidak terbuka kemungkinan sama sekali bagi Peratun untuk memeriksa, memutus dan menyelesaikannya, akan tetapi hal tersebut hanya bersifat sementara karena kompetensi absolut Peradilan TUN tersebut berlaku bagi sengketa Tata Usaha Negara yang sedang diadili oleh Peradilan Umum pada saat terbentuknya Peradilan TUN, hal tersebut diatur dalam pasal 142 ayat (1) UndangUndang Peradilan TUN yang menyebutkan : 
"Sengketa Tata Usaha Negara yang pada saat terbentuknya Pengadilan menurut Undang-undang ini belum diputus oleh Pengadilan di lingkungan Peradilan Umum tetap diperiksa dan diputus oleh Pengadilan di lingkungan Peradilan Umum.”

Dalam perkembangannya setelah 18 tahun Peratun berdiri, kompetensi absolut Peradilan TUN tersebut dibatasi pula oleh lahirnya peraturan perundang-undangan yang baru serta yurisprudensi Mahkamah Agung Republik Indonesia, yaitu antara lain

1) Pembatasan karena lahirnya Peraturan perundang-undang yang baru :

a. Undang-Undang No. 2 Tahun 2004 Tentang Pengadilan Hubungan Industrial. Sebelum Undang-Undang No. 2 Tahun 2004, perselisihan antara buruh dengan pengusaha diselesaikan oleh P4-D Panitia Penyelesaian Perselisihan Perburuhan Daerah, apabila ada yang tidak puas perselisihan dibawa ke P4-P atau Panitia Penyelesaian Perselisihan Perburuhan Pusat, apabila masih ada yang belum puas berdasarkan pasal 48 Undang-Undang Peratun dapat diajukan ke PT.TUN, sesudah lahirnya Undang-Undang No. 2 Tahun 2004 tersebut maka penyelesaian perselisihan perburuhan diselesaikan di Pengadilan Hubungan Industrial (PHI);

b. Undang-Undang No. 14 Tahun 2004 Tentang Pengadilan Pajak. Sebelum Undang-Undang No. 14 Tahun 2004 terbit sengketa yang timbul karena adanya perbedaan pendapat antara Wajib Pajak dengan Pejabat yang berwenang diselesaikan melalui Badan Penyelesaian Sengketa Pajak (BPSP), berdasarkan Undang-Undang No. 17 Tahun 1997 Tentang BPSP, apabila ada pihak yang tidak puas diselesaikan melalui MPP (Majelis Pertimbangan Pajak) dan apabila masih ada yang belum puas dapat mengajukan gugatan ke PT.TUN berdasarkan pasal 48 Undang-Undang Peratun, sesudah terbitnya Undang-Undang No. 14 Tahun 2004 penyelesaian sengketa pajak diselesaikan melalui Pengadilan Pajak;

c. Undang-Undang No. 32 Tahun 2004 Tentang Pemerintah Daerah sebagimana telah diperbaharui dengan UndangUndang No. 12 Tahun 2008. Sengketa mengenai Pemilu dan Pemilihan Kepala Daerah menjadi wewenang Mahkamah Konstitusi, sebelumnya sengketa yang tidak berkaitan dengan penetapan hasil Pemilu menjadi wewenang Peratun.

2) Pembatasan Karena Yurisprudensi MA RI 
Beberapa Keputusan yang tidak dapat menjadi objek di Peradilan Tata Usaha karena adanya yurisprudensi MA RI, antara lain :

a. Risalah Lelang Kaidah hukumnya adalah bahwa risalah lelang bukan merupakan keputusan badan atau pejabat TUN, tetapi merupakan berita acara hasil penjualan barang, karena tidak ada unsur "beslissing" maupun pernyataan kehendak dari kantor lelang, pelelangan yang dilakukan oleh kantor lelang adalah atas permintaan Pengadilan Negeri, sehingga apa yang dilakukan oleh kantor lelang merupakan tindak lanjut dari Putusan Pengadilan sehingga termasuk ketentuan pasal 2 Undang-Undang Peratun (No. 150K/TUN/1994, tanggal 7-9-1995) jo No. 47 K/TUN/1997, tanggal 26-01-1998 jo No. 245 K/TUN/1999, tanggal 30-8- 2001);

b. Sengketa Kepemilikan Tanah Kaidah hukumnya adalah bahwa Keputusan TUN yang berkaitan dengan kepemilikan tanah tidak termasuk 3 Puslitbang Hukum dan Peradilan MA RI, Kumpulan Putusan Yurisprudensi TUN, Cetak Kedua, Jakarta,2005 13 wewenang Peradilan Tata Usaha Negara, melainkan wewenang Peradilan Umum dengan melibatkan semua pihak yang berkepentingan. (No. 22 K/TUN/1998, tanggal 27-7-2001 jo $16 \mathrm{~K} / \mathrm{TUN} / 2000$, tanggal 28-2-2001 jo 93 K/TUN/1996, tanggal 24-2-1998);

c. Keputusan Tata Usaha Negara yang diterbitkan dalam rangka untuk menimbulkan perjanjian, kaidah hukumnya adalah bahwa segala Keputusan TUN yang diterbitkan dalam rangka untuk menimbulkan perjanjian maupun diterbitkan dalam kaitannya dengan pelaksanaan isi perjanjian itu sendiri, ataupun menunjuk pada suatu ketentuan dalam perjanjian (kontrak) yang menjadi dasar hukum antara kedua belah pihak, haruslah dianggap melebur (oplossing) kedalam hukum perdata, dan karenanya merupakan Keputusan TUN sebagaimana dimaksud pasal 2 huruf a Undang-Undang Peratun. (No.252 K/TUN/2000 tanggal 13-11-2000);

d. Akta Jual Beli yang dibuat oleh PPAT Kaidah hukumnya adalah bahwa PPAT adalah Pejabat TUN, karena melaksanakan urusan Pemerintahan berdasarkan peraturan perundang-undangan yang berlaku (pasal 1 ayat 2 Undang-Undang no.5 Tahun 1986 jo pasal 19 PP no. 110 Tahun 1961) akan tetapi akta jual yang 
dibuat oleh PPAT bukan merupakan Keputusan TUN karena bersifat bilateral (kontraktual) tidak bersifat Unilateral yang merupakan sifat Keputusan TUN (No. 302 K/TUN/1999, tanggal 8-2-2000 jo No. 62 K/TUN/1998, tanggal 27-72001);

e. Keputusan yang merupakan perbuatan hukum dalam ruang lingkup politik, kaidah hukumnya adalah bahwa pemilihan kepala desa merupakan perbuatan hukum yang termasuk dalam ruang politik dan didasarkan pada pandanganpandangan politik para pemilih maupun yang dipilih, hasil pilkades juga merupakan hasil dari suatu pemilihan yang bersifat umum dilingkungan desa yang bersengketa, oleh karenanya keputusan hasil pilkades tidak termasuk pengertian Keputusan TUN sebagaimana pasal 2 huruf g Undang-Undang No. 5 Tahun 1986 (No. 482 K/TUN/2003, tanggal 18-8-2004);

f. Keputusan Rektor Perguruan Tinggi Swasta Kaidah hukumnya adalah bahwa hubungan hukum antara Rektor Universitas Swasta dengan para dekan/ dosen serta lain-lain pejabat dilingkungan Universitas swasta yang bersangkutan, bukanlah dalam arti hukum kepegawaian yang termasuk dalam hukum publik, oleh karena itu keputusannya bukan merupakan Keputusan TUN yang dapat digugat din Peradilan TUN. Fakta bahwa Universitas Swasta berada dibawah koordinasi Kopertis Departemen Pendidikan bukanlah berarti bahwa Universitas Swasta berada dalam hierarki pemerintahan dan pegawaipegawainya berstatus pegawai negeri, tetapi peranan Kopertis adalah dalam rangka pengawasan agar Perguruan Tinggi Swasta dapat sudah berada dibawah koordinasi pemerintah (N. 48 PK/TUN/2002, tanggal 11-6-2004).

\section{PENUTUP}

Kompetensi Peradilan Tata Usaha Negara dalam sistem peradilan di Indonesia masih sangat relatif kecil. Yaitu hanya terhadap Keputusan TUN yang diterbitkan oleh Badan/ Pejabat TUN yang bersifat Konkrit, Individual dan Final, hal mana dibatasi pula baik oleh Undang-Undang Peratun itu sendiri, lahirnya Undang-Undang baru maupun Yurisprudensi MA RI. 
Adanya upaya pemerintah dalam reformasi birokrasi dengan merancang RUUAdministrasi Pemerintahan diharapkan mendapat dukungan dari Dewan Perwakilan Rakyat, sehingga dapat segera menjadi Undang-Undang, sehingga eksistensi Peradilan Tata Usaha Negara di masa yang akan datang dapat dirasakan manfaatnya baik bagi pemerintah maupun masyarakat

Lahirnya RUU-Administrasi Pemerintahan menjadi UU Administrasi Pemerintahan, haruslah segera ditindaklanjuti pula dengan harmonisasi terhadap ketentuan yang ada dalam Undang-Undang Peratun, sehingga kompetensi Peradilan TUN di masa yang akan datang tidak hanya terbatas terhadap Keputusan TUN saja melainkan meliputi pula semua perbuatan Badan/ Pejabat TUN yang didasarkan pada hukum publik yang menimbulkan kerugian bagi orang atau badan hukum perdata bahkan termasuk pula kerugian yang diderita oleh orang atau badan hukum perdata tersebut.

\section{DAFTAR PUSTAKA}

Darmini Roza dan Laurensius Arliman S, Peran Pemerintah Daerah Di Dalam Melindungi Hak Anak Di Indonesia, Masalah-Masalah Hukum, Volume 47, Nomor 1, 2018. https://doi.org/10.14710/mmh.47.1.2018.10-21

Laurensius Arliman S, Peranan Metodologi Penelitian Hukum di Dalam Perkembangan Ilmu Hukum di Indonesia, Soumatera Law Review, Volume 1, Nomor 1, 201. http://doi.org/10.22216/soumlaw.v1i1.3346.

Laurensius Arliman S, Peran Badan Permusyawaratan Desa di Dalam Pembangunan Desa dan Pengawasan Keuangan Desa, Padjadjaran Journal of Law, Volume 4, Nomor 3, 2017. https://doi.org/10.15408/jch.v4i2.3433.

Laurensius Arliman S, Penanaman Modal Asing Di Sumatera Barat Berdasarkan Undang- Undang Nomor 25 Tahun 2007 Tentang Penanaman Modal, Supremasi Hukum, Volume 1, Nomor 1, 2018. http://dx.doi.org/10.36441/hukum.v1i01.102 .

Laurensius Arliman S, Memperkuat Kearifan Lokal Untuk Menangkal Intoleransi Umat Beragama Di Indonesia, Ensiklopedia of Journal, Volume 1, Nomor 1, 2018, https://doi.org/10.33559/eoj.v1i1.18.

Laurensius Arliman S, Perkawinan Antar Negara Di Indonesia Berdasarkan Hukum Perdata Internasional, Kertha Patrika, Volume 39, Nomor 3, 2017, https://doi.org/10.24843/KP.2017.v39.i03.p03.

Laurensius Arliman S, Partisipasi Masyarakat Di Dalam Pengelolaan Uang Desa Pasca Undang-Undang Nomor 6 Tahun 2014 Tentang Desa, Jurnal Arena Hukum, Volume 12, Nomor 2, 2019, https://doi.org/10.21776/ub.arenahukum.2019.01202.5. Laurensius Arliman S, Mewujudkan Penegakan Hukum Yang Baik Di Negara Hukum Indonesia, Dialogica Jurnalica, Volume 11, Nomor 1, 2019, https://doi.org/10.28932/di.v11i1.1831. 
Laurensius Arliman S, Mediasi Melalui Pendekatan Mufakat Sebagai Lembaga Alternatif Penyelesaian Sengketa Untuk Mendukung Pembangunan Ekonomi Nasional, UIR Law Review, Volume 2, Nomor 2, 2018 , https://doi.org/10.25299/uirlrev.2018.vol2(02).1587

Laurensius Arliman S, Peranan Filsafat Hukum Dalam Perlindungan Hak Anak Yang Berkelanjutan Sebagai Bagian Dari Hak Asasi Manusia, Doctrinal, Volume 1, Nomor 2,2016.

Laurensius Arliman S, Ni Putu Eka Dewi, Protection of Children and Women's Rights in Indonesia through International Regulation Ratification, Journal of Innovation, Creativity and Change Volume 15, Nomor 6, 2021.

Laurensius Arliman S, Gagalnya Perlindungan Anak Sebagai Salah Satu Bagian Dari Hak Asasi Manusia Oleh Orang Tua Ditinjau Dari Mazhab Utilitarianisme, Jurnal Yuridis, Volume 3, Nomor 2, 2016, http://dx.doi.org/10.35586/.v3i2.180.

Laurensius Arliman S, Tantangan Pendidikan Kewarganegaraan Pada Revolusi 4.0, Jurnal Ensiklopedia Sosial Review, Volume 2, Nomor 3, 2020 .. 